\title{
FACTORS AFFECTING THE INCIDENCE OF ACUTE RESPIRATORY TRACT INFECTION IN CHILDREN UNDER FIVE AT BETUNGAN COMMUNITY HEALTH CENTER, BENGKULU
}

\author{
Eka Triana, Rachmadhi Purwana
}

Faculty of Public Health, Universitas Indonesia

\begin{abstract}
Background: Acute respiratory infections (ARIs) are a major cause of morbidity and mortality worldwide. Each year, about 1.3 million children under 5 years die from acute respiratory infections worldwide. ARI constitute one third of the deaths in under five in low income countries. The World Health Organization estimates that respiratory infections account for $6 \%$ of the total global burden of disease. This study aimed to determine factors affecting the incidence of acute respiratory tract infection in children at Betungan Community Health Center, Bengkulu.

Subjects and Method: This was cross sectional study conducted at Betungan community health center from Juny to July 2019. Total of 109 children under five were selected for this study by accidental sampling. The dependent variabel was incidence of acute respiratory tract infection. The independent variables were age, maternal education, occupation, smoking, room ventilation, floor condition, occupant density, and wall condition. Data were collected by a set of questionnaire and analyzed by a multiple logistic regression.

Results: As many as 25 (44.6\%) children aged o to 23 month had ARI. 32 (55.2\%) of the sample were male and 27 (52.9\%) female. $27(56.3 \%)$ parents of the children attained senior high school. The incidence of ARI in children decreased with absence of smoking habit (OR=0.24; $\mathrm{p}=0.001)$, good room ventilation $(\mathrm{OR}=0.28 ; \mathrm{p}=0.003)$, and low occupant density $(\mathrm{OR}=0.28 ; \mathrm{p}=0.002)$.

Conclusion: Incidence of ARI in children decreases with absence of smoking habit, good room ventilation, and low occupant density.
\end{abstract}

Keyword: acute respiratory tract infection, risk factor, children under five.

\section{Correspondence:}

Eka Triana. Faculty of Public Health, Universitas Indonesia. Email: ekahudi@yahoo.com. Mobile: 082179655188

\section{BACKGROUND}

Acute respiratory infections (ARI) are the leading cause of morbidity and mortality worldwide. Every year, around 1.3 million children under the age of 5 die from respiratory infections worldwide. ARI is one of three deaths in low-income countries (Tazinya et al., 2018).

In developing countries, ISPA incidents often occur with under-five mortality per 40 per 1000 live births is $15-20 \%$ per year in the toddler age group (Dongky and Kadrianti, 2016). Acute Respiratory Infection is one of the health problems in the community, it is important to pay attention. $70 \%$ of ARI occur in Africa and Southeast Asia (Winardi and Umboh, 2015).

In Indonesia ARI disease in children under five with morbidity rates 3-6 times per year (Dewi, 2012). There are two types of ARI namely the upper ARI and the lower ARI. Symptoms of ARI in children usually feel pain in the throat, colds, and cough. ARI can get worse if air pollution occurs. House air ventilation is inadequate, the area of the house is also considered whether it is sufficient for one family's purpose so that clean indoor air can be exchanged from clean and dirty air (Wangsa and Oka, 2019). 
Housing and environmental sanitation is one of the main activities in the environmental sanitation program. Sanitation housing and the environment itself is prioritized in areas that have a high risk of possible transmission of acute respiratory tract infections. And make prevention efforts on homes that do not meet health requirements (Wahyuningsih et al., 2017)

In Indonesia, efforts are made to prevent ARI by increasing the discovery of ARI in children under five. Nationally, ARI cases are estimated at $3.55 \%$ but the estimated ARI cases in each province uses figures that vary according to predetermined figures (Ministry of Health, 2018).

Basic Health Research (2018) found the prevalence of ARI under-fives of 9.3\% decreased when compared to the prevalence based on 2013 riskesdas data which amounted to $25.0 \%$. The decrease in the prevalence of ARI is due to improvements and is applied to case management and treatment of patients. The coverage of ARI sufferers in Bengkulu Province in 2018 was $20.0 \%$ and is still below the national coverage of $25.0 \%$.

Research related to the incidence of acute respiratory infections in Indonesia shows that there are several factors that influence the disease, such as economic status, inadequate environment in the house, such as lack of hygienic floors that are still in the form of soil or not made of ceramic, air ventilation which is contrary to suitability where the area of air ventilation is below the standard size of the area of each room, the number of dwellings that exceeds the standard room capacity causing high air humidity, the presence of pets in the house and smoking status in the house (Ainiyah and Handayani, 2017)

Bengkulu Province the number of patients affected by ARI in toddlers is quite high. ARI is a top 10 disease that is treated for the city of Bengkulu. ARI is ranked first out of 10 types of diseases for the Bengkulu City Betungan Health Center (Community Health Center of Betungan, 2018).

The discovery of ARI patients in Betungan Health Center shows that 3,115 of all ages in 2018, Betungan Health Center serves two villages namely Betungan Village and Pekan Sabtu Kelurahan in the Selebar Sub-District of Bengkulu City. (Community Health Center of Betungan, 2018).

In 2019 based on the poly register, children less than 5 years old / children under five are affected by ARI as many as 449 people. From observations in the working area of the Betungan Community Health Center in June - July 2019, there are semipermanent houses that are classified as houses that do not meet health requirements such as inadequate ventilation area, the condition of the house floor and wall of the house still do not meet the requirements, the number of residents houses that are not balanced with the area of the house and the behavior of residents such as smoking in the house so that it can trigger ARI in children under five.

\section{SUBJECTS AND METHOD \\ a. Study Design \\ This study was an observational study with a cross sectional research study approach. De- termination of the size of the sample is done using the Slovin formula. The sampling tech- nique of the researcher is to use the Acci- dental Sampling technique which is carried out on respondents who incidentally encoun- tered the research object. This research was conducted at the Betungan Community Health Center in Selebar District, Bengkulu City, starting from June until July 2019.}

\section{b. Population and Sample}

The population in this study were all mothers who have toddlers who are outpatient or inpatient at Betungan Health Center, Selebar District, Bengkulu City. The sample of this 
research is 109 mothers who have children under five.

\section{c. Variable}

The independent variables are knowledge, sex of toddlers, age of toddlers, density of house occupancy, type of floor of the house, condition of the walls of the house, area of ventilation of the house, and smoking habits in the house. The dependent variable is the incidence of ARI in children under five.

\section{d. Instrument}

The data was taken observational using secondary data available in the Betungan Health Center register book and primary data were the results of a questionnaire in the form of questions to respondents with the estimation results based on the complaints of the patients' parents and diagnosed with ARI.

\section{e. Data Analysis}

The analysis used is a univariate analysis to generally describe all research subjects and the variables studied, both independent variables and dependent variables using the frequency distribution table. Bivariate analysis is performed using Crosstab, which presents data in tabular form which includes rows and columns whose data are nominal and ordinal scale, with Chi-Square test to test whether there is a relationship between each independent variable on the dependent variable (Hastono, 2016).

\section{RESULTS}

The results of the study on respondents namely parents of toddlers and toddlers who have ARI, based on several factors that cause ARI.

Table 1. Characteristics of Respondents

\begin{tabular}{|c|c|c|c|c|c|c|}
\hline \multirow{2}{*}{ Variable } & \multirow{2}{*}{\multicolumn{2}{|c|}{$\begin{array}{c}\text { AIR } \\
\mathbf{N}\end{array}$}} & \multirow{2}{*}{\multicolumn{2}{|c|}{$\begin{array}{c}\text { Not AIR } \\
\%\end{array}$}} & \multirow{2}{*}{$\frac{\text { Total }}{\mathbf{N}}$} & \multirow[b]{2}{*}{$\%$} \\
\hline & & & & & & \\
\hline \multicolumn{6}{|l|}{ Age } & \\
\hline$<2$ year & 25 & $44.6 \%$ & 31 & $55.4 \%$ & 56 & $100.0 \%$ \\
\hline 2-4 year & 24 & $63.2 \%$ & 14 & $36.8 \%$ & 38 & $100.0 \%$ \\
\hline$>4$ year & 10 & $66.7 \%$ & 5 & $33.3 \%$ & 15 & $100.0 \%$ \\
\hline \multicolumn{7}{|c|}{ Toddler's Gender } \\
\hline Male & 32 & $55.2 \%$ & 26 & $44.8 \%$ & 58 & $100.0 \%$ \\
\hline Female & 27 & $52.9 \%$ & 24 & $47.1 \%$ & 51 & $100.0 \%$ \\
\hline \multicolumn{7}{|c|}{ Parents' Education } \\
\hline JHS & 8 & $57.1 \%$ & 6 & $42.9 \%$ & 14 & $100.0 \%$ \\
\hline SHS & 27 & $56.3 \%$ & 21 & $43.8 \%$ & 48 & $100.0 \%$ \\
\hline College & 24 & $51.1 \%$ & 23 & $48.9 \%$ & 47 & $100.0 \%$ \\
\hline
\end{tabular}

Source: Secondary Data of Puskesmas Betungan in 2019

Table 2. Multivariate Analysis

\begin{tabular}{lccccccc}
\hline \multirow{2}{*}{ Variable } & \multicolumn{9}{c}{ AIR Status } & OR & 95\%CI & p \\
\cline { 2 - 6 } & \multicolumn{2}{c}{ AIR } & \multicolumn{2}{c}{ Not AIR } & & \\
\cline { 2 - 6 } & $\mathbf{N}$ & $\mathbf{N}$ & $\mathbf{N}$ & & & \\
\hline Occupation & & & & & & \\
Working & 25 & $50 \%$ & 25 & $50 \%$ & 0.74 & 0.35 to 0.57 & 0.546 \\
Not working & 34 & $57.6 \%$ & 25 & $42.4 \%$ & &
\end{tabular}




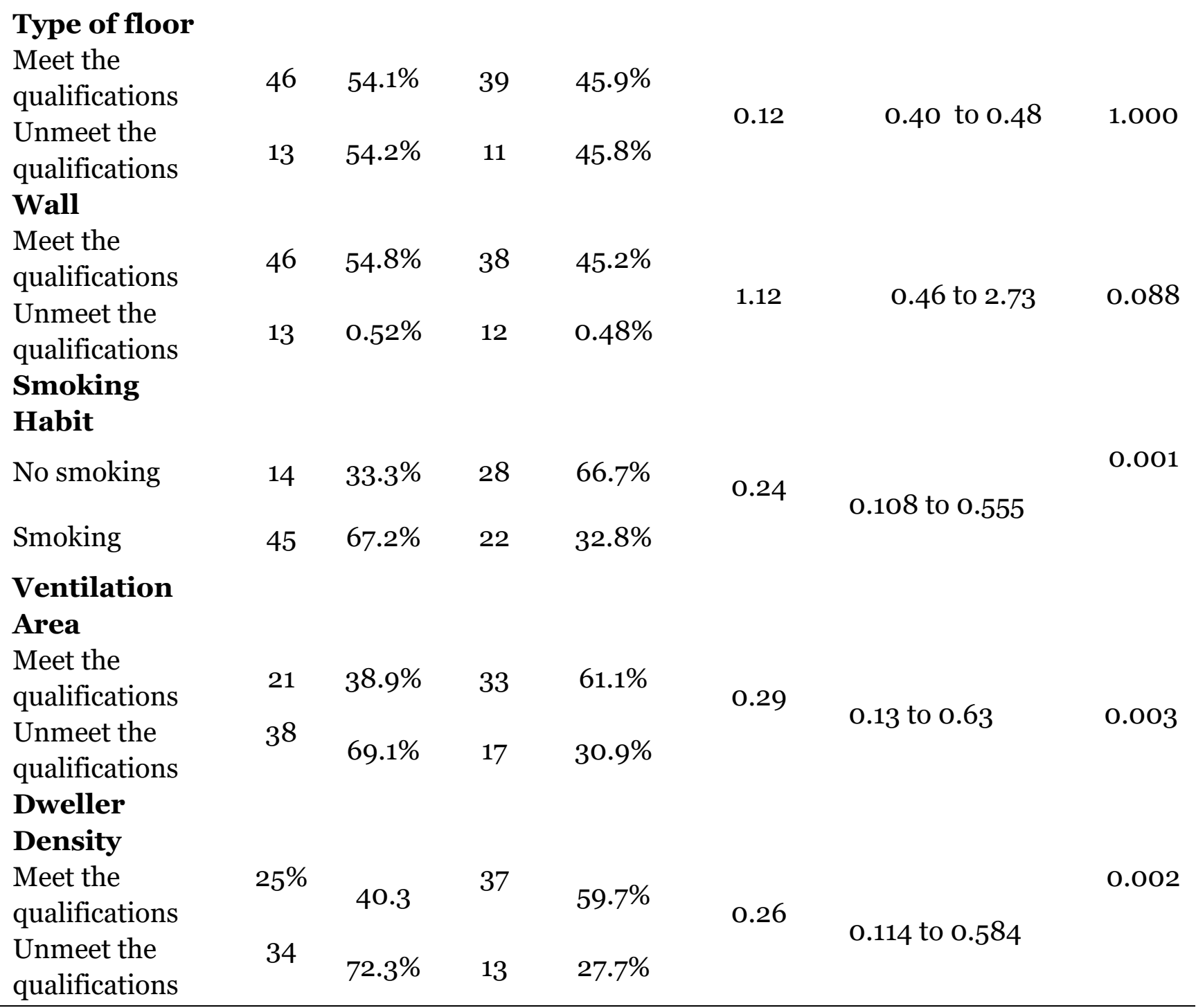

\section{DISCUSSION}

Table 1 shows the age distribution of children under five affected by ARI for each age: 2 years (44.6\%), 2-4 years (63.2\%) and $>4$ years (66.7\%). Toddlers who are not ARI are age 2 years (55.4\%), age 2-4 years (36.8\%), and age $>4$ years $(33.3 \%$. From these data, it can be seen that ARI can attack all ages. Gender distribution of children affected by ARI are male (55.2\%) and female (52.9\%). Gender distribution of children under five who are not affected by ARI is male (44.8\%) and female (47.1\%). From these data, it can be seen that ARI can attack all sexes, both male and female.

Distribution of educational status of parents of children under five affected by ISPA for each education are junior high (57.1\%), high school (56.3\%) and tertiary education (51.1\%).

Distribution of educational status of parents of children under five who are not affected by ARI is SMP 6 (42.9\%). High School Education (43.8\%) and Higher Education (48.9\%). From these data, it can be concluded that ARI does not affect when viewed from education.

Table 2 multivariate analysis shows that parents who do not work increase the risk of ARI in toddlers greater than working parents $(\mathrm{OR}=0.74 ; 95 \% \mathrm{CI}=0.35$ to $0.57 ; \mathrm{p}=0.546)$. However, this is not statistically significant. The type of house floor that meets the requirements increases the risk of ARI in 
toddlers greater than the type of house floor that meets the requirements $(\mathrm{OR}=0.12 ; 95 \%$ $\mathrm{CI}=0.40$ to $0.48 ; \mathrm{p}=1.000)$. However, this is not statistically significant. House walls that do not meet the requirements increase the risk of ARI in children under five more than those that meet the house requirements $(\mathrm{OR}=1.12 ; 95 \% \mathrm{CI}=0.46$ to $2.73 ; \mathrm{p}=0.088)$. However, this is not statistically significant. Parents who smoked increased the risk of ARI in toddlers greater than those who did not smoke $(\mathrm{OR}=0.24 ; 95 \% \mathrm{CI}=0.11$ to 0.56 ; $\mathrm{p}=0.001)$ and were statistically significant.

The area of ventilation that does not qualify increases the risk of ARI in infants greater than the area of ventilation that qualifies $(\mathrm{OR}=0.29 ; 95 \% \mathrm{CI}=0.13$ to 0.63 ; $\mathrm{p}=0.003$ ) and is statistically significant. The density of residents who do not meet the requirements increases the risk of ARI in children under five years greater than those who meet the requirements $(\mathrm{OR}=0.26 ; 95 \%$ $\mathrm{CI}=0.114$ to $0.584 ; \mathrm{p}=0.002)$ and is statistically significant.

The results of the study in June to July 2019 of 150 patients in poly children aged o to 5 years from 109 samples contained 59 infants affected by ARI and 50 toddlers who were not affected by ARI. Based on data obtained from the Bengkulu City Betungan Health Center in 2019, it is known that the number of ARI patients is the most common disease found in the Betungan Health Center. This shows that there are many factors that must be considered related to ARI in Bengkulu City's Betungan Health Center in 2019.

There are several factors to be observed that are expected to influence the incidence of ARI in infants at Betungan Health Center in Selebar District of Bengkulu City in 2019 and from the results of calculations through the SPSS Application of the 9 independent variables found 3 factors related to the incidence of ARI in toddlers in Betungan
Public Health Center, Selebar District, Bengkulu City in 2019, namely ventilation area, smoking habits in the house and density of residents.

\section{REFERENCES}

Ainiyah N. Handayani. D (2017). Jurnal Ilmiah Kesehatan. Hubungan Tingkat Pengetahuan Ibu Tentang ISPA Dengan Sikap Ibu Tentang Pencegahan Penularan ISPA Pada Bayi Usia ohingga12 Bulan Di Puskesmas Pandaan (The Relationship between Mother's Knowledge Level about ISPA and Mother's Attitude About Prevention of ISPA Transmission in Infants 0 to 12 Months at Pandaan Health Center). 10: 60-65.

Community Health Center of Betungan (2018). Laporan lahunan Puskesmas Betungan Kota Bengkulu (Report on the birth of the Bengkulu City Betungan Health Center).

Dewi A (2012). Hubungan Kondisi Lingkungan Fisik Rumah dengan Kejadian ISPA pada Balita di Wilayah Kerja PUSKESMAS Gayamsari Kota Semarang (Relationship between the Physical Environment Conditions of the House and the Occurrence of ARI in Toddlers in the Gayamsari PUSKESMAS Work Area, Semarang City). Jurnal Kesehatan Masyarakat. 12: 852-860.

Dongky P. Kadrianti K (2016). Faktor Risiko Lingkungan Fisik Rumah Dengan Kejadian Ispa Balita Di Kelurahan Takatidung Polewali Mandar (Risk Factors for Physical Environment of Houses with the Events of Toddler's Disappearance in the Takatidung Village Polewali Mandar). Unnes Journal of Public Health. 54: 324. https://doi.org/10.15294/ujph.v5i4.13962

Hastono S (2016). Analisis Data pada Bidang Kesehatan (Data Analysis in the Health 
Sector). Jakarta.

Ministry of Health (2018). Indonesian Health Profile. Jakarta.

Tazinya A, Hallehingga E, kane G. Mbuagbaw L, Abanda M, Atashili J, Obama MT (2018). Risk factors for acute respiratory infections in children under five years attending the Bamenda Regional Hospital in Cameroon. BMC Pulmonary Medicine. 181: 1-8. https://doi.org/10.1186/s1289ohinggao18hinggao579hingga7

Wahyuningsih S, Raodhah S. Basri S (2017). Infeksi Saluran Pernafasan Akut ISPA pada Balita di Wilayah Pesisir Desa Kore Kecamatan Sanggar Kabupaten Bima (Acute Respiratory Infection ISPA in Toddlers in Coastal Areas of Kore Village, Sanggar District, Bima Regency). Higiene. 32: 97-105.
Wangsa A, Oka P (2019). Proses Kerja Dokter pada Anak Penderita ISPA di Desa Banjar (Working Process of Doctors in Children with ISPA Patients in Banjar Village). Banjar. Buleleng. Bali.

Winardi W, Jootje M. Rattu A (2015). Hubungan kondisi lingkungan rumah dengan kejadian ISPA. Hubungan Antara Kondisi Lingkungan Rumah Dengan Kejadian Penyakit ISPA Pada Anak Balita di Wilayah Kerja Puskesmas Sario Kecamatan Sario Kota Manado Correlation (Relationship between home environment conditions with ARI events. The Relationship Between Home Environmental Conditions and the Occurrence of ARI Disease in Children under five years old in the Working Area of the Sario Health Center, Sario District, Manado City Correlation). 